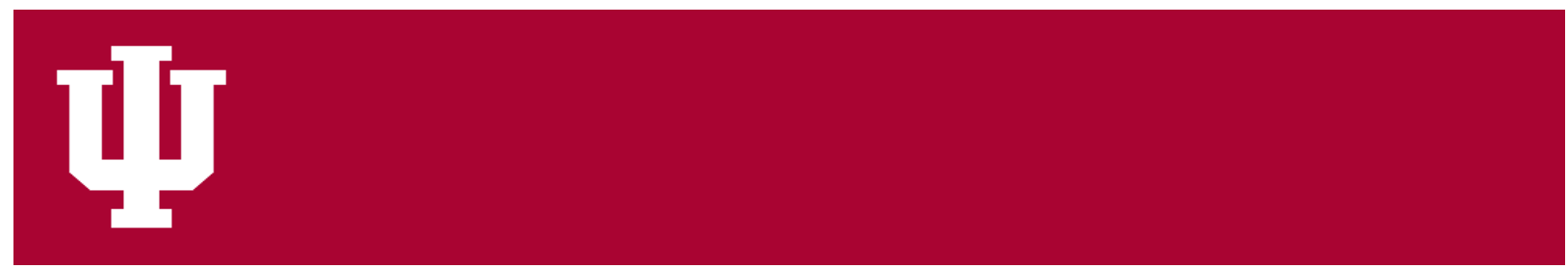

IUScholarWorks at Indiana University South Bend

\title{
Killing the Documentarian: Richard Wright and Documentary Modernity
}

Balthaser, Benjamin

To cite this article: Balthaser, Benjamin. "Killing the Documentarian: Richard Wright and Documentary Modernity." Criticism, vol. 55, no. 3, 2013, doi:DOI: 10.13110/criticism.55.3.0357.

This document has been made available through IUScholarWorks repository, a service of the Indiana University Libraries. Copyrights on documents in IUScholarWorks are held by their respective rights holder(s). Contact iusw@indiana.edu for more information. 


\title{
Killing the documentarian: Richard Wright and documentary modernity.
}

\author{
Benjamin Balthaser
}

\author{
Criticism 55. 3
}

As Bigger Thomas sits wedged uncomfortably between the young, would-be radicals Jan and Mary, Mary touches Bigger's arm and gestures to the "tall, dark apartment buildings" of Chicago's South Side, telling him, "You know, Bigger ... I've long wanted to go into these houses ... and just see how your people live." (1) To anyone familiar with the history of documentary photography, it's hard not to read this scene early in Richard Wright's Native Son (1940) as a pointed satire of the documentary aesthetic. Mary's comment that she wants to "see how your people live" carries with it strong connotations of Jacob Riis's seminal How the Other Half Lives (1890), emphasizing the documentary's power of sight to interpret, interpellate--and invade--the "dark" and seemingly unknowable lives of the poor and marginal. Likewise, that her statement is made as Mary imposes an unwanted, or at least highly transgressive, intimacy between she and Bigger further suggests the ways in which the documentary impulse is one of crossing barriers and borders--an impulse that often works to reinscribe as much as to overcome the privilege on which the borders are founded. As a figure of the documentarian, Mary Dalton fits this role all too tragically: a wealthy progressive who believes that if she is allowed "to see" the conditions in which poor African Americans live, this uniquely visual regime of knowing will transform her and lead her to political action. This emphasis on sight, underscored by Wright's italics, as the crucial precursor to progressive change is, as critics have argued, the ontology of the political documentary. That Jan and Mary have essentially kidnapped their black subject of knowledge and that their act of "vision" on the South Side produces race/ism rather than resolves it could easily be taken as Wright's final statement on the 1930s radical documentary.

For all of Wright's pointed satire, it's equally important to note that less than a year after the publication of Native Son, Wright edits a selection of documentary photographs that do exactly what Mary expresses she wants to do: go into "tall, dark apartment buildings" and "just see" how Wright's people live. As Native Son murders its own white documentarian, then we must ask what the relationship is between Mary's misguided, ultimately deadly desire to see and even touch how the Other lives and Wright's own documentary impulse to do just that in 12 Million Black Voices (1941). I would argue that 12 Million Black Voices--Richard Wright's documentary photo-montage of the Great Migration--is not merely the nonfiction companion to Native Son as it was advertised, but rather the culmination of Wright's own contradictory and dialectical concerns with the politics of black representation. In "killing the documentarian"--the white chronicler of black life--Wright does not abandon the public sphere dominated by a white gaze. As documentary photography has been a significant means by which the West has constructed and codified modern ideas of race, Wright's critique of the mode and his insistence on its constructed nature call into question the very possibility of a visible regime of knowing. Yet, the documentary is also the form perhaps most associated with the political and representational projects of modernity. As Paula Rabinowitz notes, documentary photography is also the medium that can translate the present into the future and redeem, in a Benjaminian 
fashion, the wreckage of history. (2) Thus, for Wright, the documentary image stands at just that nexus of historical trauma and liberation that ends 12 Million Black Voices, the "living past living in the present" and the "new procession" and "new tide" of revolutionary progress. (3) Like Wright's own contradictory statements on modernity, at once based on the "deadly web of slavery" and "higher human consciousness," photography for Wright becomes an expression of a racial past, as well as a liberatory future. (4) For Wright, the documentary image's dialectical mode--containing technologies of both liberation and domination--is thus Wright's precise claim on African American modernity.

It should also be noted that Wright retermed W. E. B. Du Bois's formulation of double consciousness--experiencing the self as both inside and outside of the Western gaze--as double vision, locating the central experience of hybrid consciousness in compellingly visual terms. Yet, what does it mean to see double consciousness or for consciousness to be rooted in visual representation? As recent critics such as Maurice Wallace, Sara Blair, Joseph Entin, and Abdul JanMohamad suggest, there is an obsessive fixation on the "picture-taking racial gaze" in Native Son, in particular the documentary image for its role in establishing the "truth" about race and other forms of social being. (5) Documentary, more than any other pictorial form, rests its power on the self-evident specular truth that it produces. For Wright, ever the dialectician, the method of racial freedom lay in the very mode of oppression. If the modern idea of race as an ocular fact is at least in part constructed from a documentary regime of knowledge, then it is at least in part through the commandeering of the logic of representation that one can find a way out. Deployed as radical montage in 12 Million Black Voices, Wright creates a dialectical image that moves the reader both forward and backward through history simultaneously as a way to represent the "twoness" of African American life visually within the West.

Yet, unless one takes the entire oeuvre of Wright's work on the documentary, from Native Son through 12 Million Black Voices and finally to his 1954 travel writing of preindependence Ghana Black Power (1954), it's difficult to grasp both the dedication and the painful selfconsciousness Wright attached to the documentary image. Wright places the role of documentarian in his most celebrated work, Native Son, with the unreliable but nonetheless powerful subjective gaze of Bigger Thomas himself, whereas, a decade later, Wright himself refuses to include documentary images of Ghana in Black Power in an implicit acknowledgment of the inherent Occidental nature of the documentary image. Considering these modes of documentary within Wright's work, one can gain a broader sense of Wright's visual metaphor of double consciousness--what it means to "see" as a Western subject and object--and how Wright deployed documentary visual culture as a way to articulate the painful entrance and participation of African-descended peoples globally into modernity. "Double vision" places racial identification critically within the realm of sight and, as these works suggest, within the ability of the documentary to capture and produce knowledge about a racial subject. That Wright was unable to reconcile his "views" of documentary--as a mode of liberatory and oppressive racial meaning--suggests that he was caught within the very contradiction he attempted to document in earlier works.

As many critics and biographers have noted, Wright was a voracious consumer of films, including documentary--not only was he an amateur photographer, he had once applied to the Film Board of Canada in the hopes of making a documentary film. (6) As a product of 1930s 
revolutionary culture, Wright's engagement with documentary photography as a genre should come as no surprise. The 1930s and 1940s were the golden age of the photo-documentary, and the decade that witnessed the transformation of the genre from an act of state and civic surveillance to--in the hopes of some, at least--a subjective expression of the disempowered and disenfranchised. Of course, this transformation was far from total, and much of even the radical documentary projects of the 1930s and 1940s inherited the racial and classed habits of seeing that mark the genre's genesis in the nineteenth century.

As Shawn Michelle Smith argues, photography in the middle to late nineteenth century trained the American eye to "see established social hierarchies" as "anchored in ... visual 'truths."' (7) Using the scientific and sentimental discourses of photography to produce essentialized realities about differentiated bodies, photography, Smith suggests, became the privileged social structure that produced a dominant white, middle-class subjectivity. (8) Smith chronicles the way in which the "private" practice of portraiture and child photography in middle-class white homes worked to reinforce normative views of whiteness in conjunction with the "public" photographic practice of eugenics, lynching postcards, phrenology, and police mug shots that worked to define black bodies as deviant, criminal, and primitive. Equally reliant on photographic documentation was the racial typology of African Americans and white ethnics as practiced by eugenic theorist Francis Galton. Creating composite photo-montages of racial "types," Galton managed to infuse race within the habits and practices of visual culture, reinforcing the biological essence of a body that could be documented by the ocular scientific image. (9) Race, Smith argues, became a way of seeing through the documentary image--photography came into being not merely as a tool of racial segregation, but by shaping and codifying the way in which racial knowledge came to be disseminated and understood. Or, as Deborah Willis phrases it, photography was by and large a medium about African Americans, rarely by and for them. (10)

It would be tempting to think that the muckraking documentary photography of the 1880s broke with the tradition of eugenic and surveillance photography, or at least posed an alternative way of seeing, because it was produced for the putative benefit of the urban poor. Yet, as Maren Stange suggests, Jacob Riis's text often credited with beginning the tradition of progressive documentary photography, How the Other Half Lives, was as much about social change as about naturalizing the "colonial" position of the middle class in relation to the residents of the city slums. (11) Riis, who began his career in photography as a police reporter, led his mostly propertied middle-class viewers through a lantern slide show as the "guide and conductor," reassuring "this half" of their position of privilege and collective security. (12) Much like the craze for moving panoramas of the Wild West in the 1850s--giving rise to Buffalo Bill's career as a similar kind of guide through his vision of Western history--the purpose of these images was not to frighten viewers but offer a way to locate, categorize, and ultimately domesticate what was seen as an unruly element at the nation's periphery. (13) As Stange points out, many of the images from How the Other Half Lives were themselves staged reproductions of police-gazette images, framing amelioration of poverty as benevolent social control, a way to prevent criminal activity, including radical labor organizing. Ultimately, Riis's camera work shared more in common with Galton's eugenic typology, encoding and objectifying residents of New York City's slums as part of a regime of social and territorial control. And, like the fictional Mary Dalton of a later generation, Riis's social work, and Buffalo Bill's Wild West tours, the capturing sight of the documentarian was a crucial element of the apparatus of control. 
The Farm Security Administration (FSA) photo project can be seen as both a break with earlier traditions of documentary photography and their continuation. Easily the largest documentary photo project conducted by a government agency in US history, many of the stated aims of Roy Stryker, the project's director, were similar to those described by Riis--to represent poverty to a middle-class audience who had, through the growth of new government social programs, a sudden social interest in the poor. (14) Stryker's editorial selections emphasized photographs of white subjects, featuring portraits of mothers and children, thus constructing the "deserving" poor as largely rural, racially homogeneous, and Protestant. These editorial selections suggest not only the limits of the project, but the ways in which Stryker openly promoted a classed and raced vision of poverty. (15) Even so, Stryker's conservative vision of the FSA still managed to challenge the role of documentary photography in the way it represented class. Indeed, one could say that the power of Dorothea Lange's 1936 Migrant Mother image is that it grants to a white working-class woman the stature, poise, and intimacy reserved for middle-class portraiture. Unlike the racial and classed documentary of Riis or Galton that served to objectify its subjects within a scientific discourse of power, the middle-class portrait according to Smith was to demonstrate an individuated essence, a "humanized" and "inward feeling" that refused easy interpellation into surveillance regimes. (16) Thus, the conservatism of the FSA did not produce so much a biologically or territorially marked subject for further surveillance and classification, but rather brought a deserving poor within a larger paternal discourse of the middle-class family in which the FSA subject would be the newest member.

The racial limits of this project are often quite stark. If the most memorialized photograph in the FSA collection is Lange's Migrant Mother, one must ask what the representation of another group of migratory farmworkers taken the same year may suggest (see figure 1). With their faces obscured, their bodies wrought at sharp angles, and their hats creating angular shapes in place of the workers' heads, Filipino Workers Cutting Lettuce is an image of mechanized, alienated labor-and nothing more. If the migrant mother is brought within the scope of the paternal national family discursively through Lange's image and financially through taxpayer-supported FSA relief programs, then these Filipino lettuce cutters may earn sympathy, but their stature as tools of farm capital in these images reads them out of the sentimental racial and gendered narrative that the FSA wanted to tell. Indeed, many of the most memorialized FSA photographs would seem to underscore the racial vision of the project-Arthur Rothstein's photo of an Oklahoma dust storm, Walker Evans's tenant-family portraits, and Russell Lee's photo of children standing to eat their Christmas meal--all reinforce the whiteness of the photographer's gaze, presenting the racial family unit as the conveyor of national worth. If the absence of African Americans within the public sphere created by the FSA is cause for question, then within the documentary field of the 1930s the presence of African Americans by and large traded on familiar patterns. Doris Ulmann's 1933 Roll, Jordan Roll present African Americans within a premodern agrarian idyll, whereas Margaret Bourke-White and Erskine Caldwell's 1937 best-selling photo-expose of tenant farming in the Deep South, You Have Seen Their Faces, tend to represent African Americans as slow-witted and sleepy, under captions that narrate black children "coming along like watermelons in the summer." (17) 
Caldwell's companion text is quite revealing of the contradictory ways in which African Americans were represented by a sizable current within the 1930s New Deal coalition. While African American sharecroppers are described as "slaves," they also lack the same political agency and will that the white tenant farmers display. Devoting only three pages of a forty-fivepage essay to black tenant farmers, Caldwell suggests in a tone reminiscent of the antebellum South that the black tenant farmers are "well satisfied at their place" as long as they manage to find the right "plantation." (18) In an anecdote likely authored by Caldwell, a first-person narrator tells of how a white landlord "sent a colored family down to move into our house" after the white farmer insisted on his full pay. (19) Ultimately, African Americans in the South are seen as adjuncts of the sharecropping system itself--victims, perhaps, but lacking the will for freedom that would make them democratic political subjects, and callously manipulated by the white landlords so as to discipline rebellious white tenants. The images in the text--lacking in the overt racist typology one would see in Life magazine of bestial, watermelon-eating women-nonetheless depict African Americans reclining, sleeping, or "[j] ust sitting and watching the Mississippi go by" rather than working the fields. (20) Although the collection ends on the hopeful note that the tenant farmers might organize into a union, it's clear that the tenants Caldwell imagines as political subjects and agents of the South's collective history from neofeudalism to development will be white.

As Nicholas Natanson points out in The Black Image in the New Deal (1992), the FSA nonetheless managed to produce more images of black life than any previous or even later government collection. (21) In terms of total numbers, nearly 10 percent of the images produced were of African Americans, a number that nearly coincides with the proportion of African Americans in relation to the US population as a whole. Even before the publication of 12 Million Black Voices in the early 1940s or the hiring of Gordon Parks, the FSA's first African American photographer a year later, the images of black tenant farmers and black residents of Southern cities were often sensitive and complex renditions of African American life. Completely absent were portraits of simple agrarian folk, pathological victims, or sullen mug shots of the criminal underclass. Indeed, as Natanson suggests in the first chapter of his monograph, images like Marion Post Wolcott's Negro Man Entering a Movie Theater by 'Colored' Entrance (1939) are complex, ironic takes on the integration of mass culture into the politics of segregation. (22)

Despite this relative advance, though, nearly all of the images produced by the FSA of African Americans were rural, either of small Southern towns or sharecroppers in the South. And while Gordon Parks and Aaron Siskind both photographed African Americans in complex situations in modern, urban settings, until the publication of Edwin Rosskam and Wright's 12 Million Black Voices and the Office of War Information's coverage of defense plants, the great migration and life of urban African Americans were entirely undocumented in large-press book form. (23) Missing from the FSA were images of the black struggles for civil rights and labor rights, as well as overt acts of racism, such as voter disenfranchisement or lynching. In part, this latter omission was due to the very real dangers the photographers and their subjects faced if such images were released and, in the case of the FSA, in large part due to Southern political pressure on the Roosevelt administration. (24)

For whatever the reason, the outcome of the FSA images prior to Parks's 1940s images was very much in line with Caldwell's narrative about African American struggle: African Americans may 
be unfortunate victims but are not the centerpiece of struggle nor at the center of the US narrative about the Great Depression. Rather than being an aberration in the representation of African Americans in the 1930s liberal Left, the accretion of black images and black bodies to what was at heart a white, republican project placed the FSA on a continuum of black representation in which their own history and their relationship to modernity was denied. As C. L. R. James writes in the "Stalinism and Negro History" (1994), "[I]n the ... Marxist writings of the 1930's, the Negro is present, but only as a soldier, an officer, as deserving of 'recognition' for their bravery, service, etc." (25) The FSA added a proportional number of African Americans to their rolls, yet, as James argues about African American history, a "particular subjectivity" to African American struggle includes but is also independent of US white national history--and this particular subjectivity was glaringly absent in the FSA project. (26) If documentary photography is to "take the past into the future," it is clear that, for much of the documentary representation of the 1930s, African Americans are relegated to a slave past rather than to a modern future in which their struggles for liberation are the center of a radical modern and democratic project. (27)

Seeing Your People: Bigger Thomas as Documentary Photographer

Despite Wright's fame as a radical protest writer of realist fiction, many critics have noted the surprising instability of reality that pervades many of his most famous texts--as Amrit Singh suggests, there is a "war over the nature of reality" that "blacks and whites are engaged in." (28) Even in Wright's earliest writings, we can see a racial and classed struggle over the meaning of mass-culture images. Several years before the publication of Native Son, Wright penned a number of short essays and articles about African American heavyweight boxing champion Joe Louis for the Communist Party's two main journals, the New Masses and the Daily Worker. Nicknamed the "Brown Bomber," Louis was hailed as a celebrity among African Americans for defeating white heavyweight champion Max Baer and among antifascists for defeating Germany's Max Schmeling, the boxer promoted by the Nazis as an example of Aryan superiority.

Yet, in the first of Wright's articles, "Joe Louis Uncovers Dynamite" (1935), Wright talks little about the international dimensions of the prize fight. Instead, he focuses on the effect of Louis as a racial symbol, the spontaneous "tidal wave" of joy in Chicago's black South Side after the 1935 defeat of Baer by Louis. (29) Describing the "explosion" of working-class black men from "beer taverns, pool rooms, barber shops, rooming houses and dingy flats" into the streets, Wright is quick to locate the meaning of Louis's victory as mass psychology: Louis's victory "ripped loose" the racial unconscious of the city as both blacks and whites began to "feel themselves" racially: "Joe was a consciously felt symbol. Joe was the triumph of black over white." (30) Not only does Wright acknowledge the way in which race is a mediated experience, that experience is structured by and spoken through mass-culture images that constitute a terrain of struggle between racially defined groups. While racial meanings may be latent for Wright, racial expression is not rooted in an essential biological identity or even in stable cultural practice: rather, the media figure of the boxer organizes the racial experience in radically divergent ways for different populations.

Wright's reportage about Joe Louis emphasizes that racial identity and racial consciousness are mediated through mass culture, while Native Son reminds us that this is hardly a neutral or even 
process. (31) As many have pointed out, Bigger himself is a product of sensational gangster films and crime novels, and the story of Mary's murder Wright self-consciously altered from a tabloid murder. Although Wright has been criticized most famously by James Baldwin for reproducing stereotypes of black criminality, Wright is doing something far more complicated-suggesting ways in which working-class blacks are themselves interpellated in their own racist representation, and how their ability to resist is thus necessarily circumscribed. Viewing the Daltons on a newsreel before he is to report to his first day of work, Bigger is seduced by the Dalton's celebrity, convinced he is going to on to "something big" as he gazes at images of Mary and Jan on the Florida coast. (32) As the feature film Trader Horn (1931) unfolded scenes of African savagery, with "naked black men and women whirling in wild dances," Bigger "replaced" them with a steady litany of constructed images of whiteness: "[R]ich white people were not so hard on Negroes; it was the poor whites who hated Negroes ... it was rich white people who were smart and knew how to treat people ... a Negro chauffeur ... married a rich white girl and the girl's family had shipped them out of the country and supplied them with money." (33) This binary scene of black primitivism and white wealth/rationality suggests that these images not only occupy the same discursive and physical space inside the theater, but that Bigger's very imagination of whiteness lay in a dialogic suppression of images of degraded blackness.

As critic Joseph Entin points out, after Bigger's capture by police, his ability to resist his encoding within racist visual culture is limited. In an amazing scene in which Wright displays the ways in which images of race are constructed through the mobilization of black bodies, journalists lead Bigger back to Mary's bedroom to photograph him reenacting what they believe to be his murder of Mary:

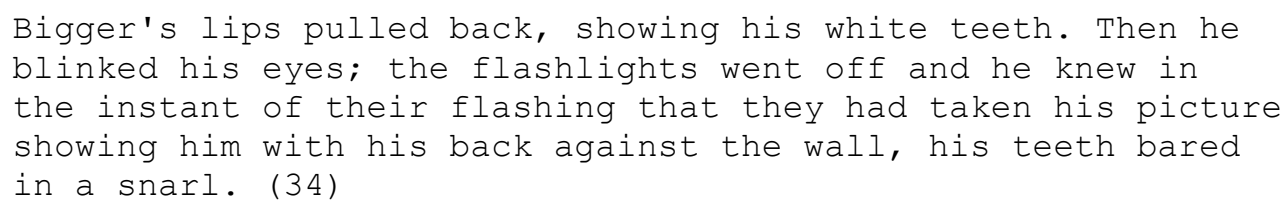

As Entin suggests, in this scene flashbulbs are "analogous to pistols," literally framing Bigger within a fatal entanglement of media images and carceral violence that close around him ever more tightly despite or, rather, because of his efforts to resist. (35) As he lifted racist lines directly from the sensational crime reporting of a young African American accused of murdering a white woman, Wright revealed the way in which African Americans are conscripted into media narratives that serve to further their subjugation. I would suggest that Bigger's entire series of actions, from his plot to rob Blum's cafeteria to his attempt to extort ransom from the Daltons, are his attempt to control the symbolic racial codes of his universe--to rewrite, if you will, the pulp novel in which his racialized body has been scripted.

In this context, when Bigger accepts responsibility for the death of Mary, that "what I killed for must have been good," he suggests that the symbolic meaning of Mary as a white woman is real even if he understands by this point that her death can no longer liberate him. (36) Indeed, to the extent that her death and life structure the reality of Bigger, his insistence that he lives in a world in which these constructed representations are "real" and that he "killed for something" is true. In 
one of the seldom-mentioned facts about Bigger's life, his father was killed in what Bigger refers to as "a riot," an event that was as likely a lynching. (37) If Mary's death organizes the symbolic meaning of both whites and blacks in the text, then the unrepresentable fact of Bigger's father's death--spoken only as a euphemism in the text-fulfills the dialectic opposite of both Bigger and Mary's hypervisibility on a newsreel earlier the same day. In this way, Mary not only wishes "to see how your people live," but her presence literally renders the life and death of his family unknowable. The "not real" and symbolic body of Mary murders yet again the real and invisible body of Bigger's father. Bigger's desire to "blot out" the Black Belt after Mary's stated desire to "to see" it is merely the psychological representation of the way her body, against her own will, is used to do just that.

Mary's death does more than set Bigger temporarily free: Bigger seizes from Mary her professed role as documentarian and renders the South Side suddenly visible. Bigger awakes the next morning after Mary's death with a sudden ability "to see" his family in new ways--ways that often correspond with the distanced, removed role of the documentarian. While Bigger is on the run from the law and hiding out in the vacants, he assumes the role of documentary "spy" representing the intimacies of urban black life with a distanced, and even critical, eye. Much like the documentary photographers of the 1930s, Bigger spies on the private lives of South Side residents, peering into the beds of one-room "kitchenettes," into the storefront churches, and eavesdropping on the private conversations of men on street corners and in bars, offering social commentary much like a documentary artist, suggesting the ways in which segregation produces a contradictory black culture. In the first of these, Bigger sees

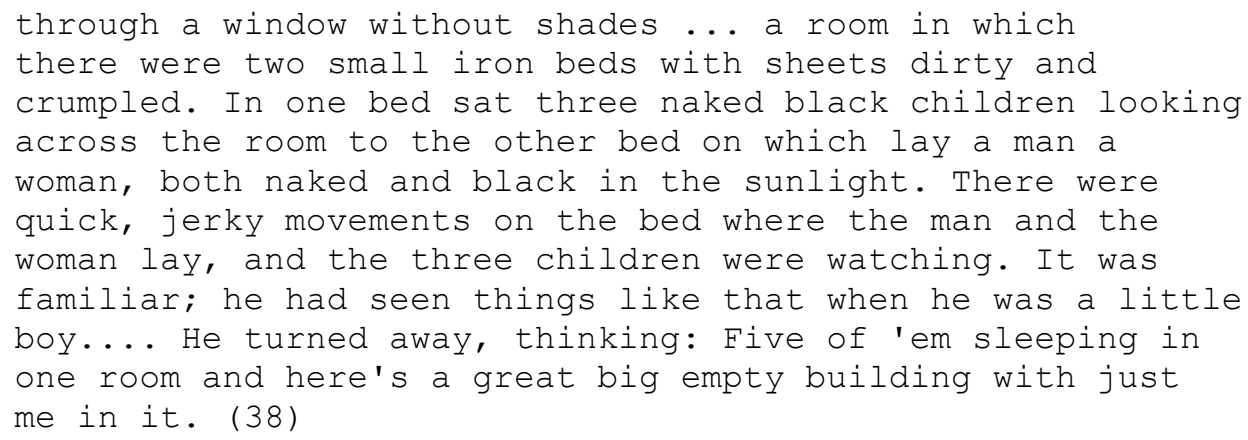

This passage, and the two immediately following it, summarize the documentary gaze: offering a glimpse into the "hidden" reality of a subject ordinarily obscured from view--an image that speaks to a "pathological" or forbidden behavior. As Freud states, the postnatal amnesia that children suffer is precisely to "hide" scenes of intimacy between children and parents and between parents themselves, including birth, breastfeeding, and parental sexual relations--thus, the viewing that Bigger shows the reader is taut with the scopic voyeurism of the camera eye. And inseparable from the scene's pathology is the fact of the couple's blackness, mentioned twice in the text, coding the fraught scene within a visible regime of racial knowing. As with the documentary tradition, Bigger contextualizes the racial and individual behavior within a larger structure of social inequality, hoping to transform pathology into social action.

The two following scenes are similar in the sense that they reveal aspects of black life usually hidden from the public (white) gaze. The first is a conversation between two men about Bigger 
that oscillates between shame ("so many of us ack like Bigger Thomas") and defiance ("They don't care whut black man they git.... Yuh gotta stan' up n' fight these folks"), emotions that, again, are usually forbidden to speak in public, and emotions that Bigger often tries to keep hidden within himself. (39) The final scene that Bigger observes while hiding in the vacants is a church service in a storefront in which women sing the spiritual "Steal Away to Jesus," again expressing the twin emotions of humility and defiance, a compromise that Bigger would "never do." (40) The scenes described here are very similar to those included in 12 Million Black Voices and other photographs of urban black life by Gordon Parks, as well as by the Workers Film and Photo League--including the small apartments and the storefront churches. The images Bigger relates are significant in two primary regards--each is predicated on a complex, often contradictory set of emotions, and, more importantly, Bigger himself identifies emotionally and even experientially with the people he observes, noting that "many mornings he had awakened and watched his father and mother" and that the women in the church were of "his mother's world." (41)

Bigger's transformation from thug to documentarian raises this intriguing question: What is it about Bigger that led Wright to choose him for his documentary camera eye? Indeed, Wright describes Bigger as a kind of recording instrument late in the novel, a machine whose hands "were electric wires" with the seemingly contradictory mission to "find out if other hands connected with other hearts" through the connectivity of the electric shock. (42) In many ways, this would be an apt description of the task of the documentary photographer, one who works in order that others may receive a "shock of recognition." (43) As the documentary eye is the machine intended to redeem humanity precisely through its mechanical objectivity, it would seem to necessitate someone who is both an outsider and--for those who are concerned with the politics of representation--one who can nonetheless represent the people whom she or he photographs.

I suspect that it is just Bigger's contradictory role as a character that makes him for Wright the perfect vehicle for the radical documentary gaze. Bigger appreciates the lure of modernity--he desires to be an airplane pilot, "hungers" for films and sensational magazines--and is yet fundamentally denied access to the benefits of the modern world. Bigger is also crosscut by alternating currents of black nationalism and nascent cross-racial alliances--someone who kills as a response to his subjective experience of blackness and yet finds an elderly white lawyer as his sole friend. In this sense, Bigger lay at a nexus of modernity and exclusion, political possibility and repression, signifying both the subject and object of the documentary photograph. As Abdul JanMohamad articulates, it is just Bigger's capacity to be subject and object at the same time-victim and rapist, murderer and object of violence--that constitutes his own alienated double consciousness. (44) It is also this capacity that enables him to become the documentarian of Native Son.

\section{Million Black Voices and Black Modernity}

If Thomas's authority as a documentarian for the black working class evolves from his own position within it, it's crucial to note that his political transformation at the end of the novel is framed as an act of viewing by a white leftist. When Jan comes to offer help to Bigger--and to express how much Bigger's act has transformed him--Jan momentarily assumes the role of the 
documentarian opening up Bigger's life to view: "[S]uddenly this white man had come up to him, flung aside the curtain, and walked into the room of his life." (45) Looking, and allowing oneself to be seen, are inherently political acts for Wright. As much as Thomas is constituted as a political subject by his refusal to be seen by Mary, his final transformation into political consciousness comes paradoxically by way of his permission to allow Jan to "pull open the curtain." In this manner, the novel comes full circle--from a mutually constituted vision of black primitivism to a mutually constituted view of multiracial democracy. Although Wright may condemn Du Bois's documentary project of the "talented tenth" in the name of proletarian black subjectivity, to allow for expression within only a single racial or classed community would condemn the documentary to the prepolitical for Wright--and deny the project the space in modernity that Wright demands. For Wright, the documentary is not only a question of representation--rather, it is also a political project, a claim for a particular vision of modernity rooted in an African American experience.

The choice of Bigger as documentarian stands in direct challenge to earlier forms of African American resistance to white representational modes. As Shawn Michelle Smith chronicles, Du Bois compiled and composed hundreds of photographs of African Americans for his American Negro Exhibit at the 1900 Paris Exposition. The photographs were largely staged, formal portraits of well-to-do, urban, educated African Americans from the Atlanta area: Du Bois's "talented tenth" of "influential and forceful men." (46) As a part of the Paris Exposition, these images existed within a scientific discourse that coded peoples of African descent as examples of biological difference, offering images and measurements of African bodies to display their evolutionary and biological primitivism. As a collector of images, Du Bois intended the generally middle-class portraits to be a counterarchive presenting an antiessentialist methodology that could challenge the eugenic racism of visual documents on display at the exposition. (47) Although Smith argues there is a significant variation of expression and feeling within the portraits compiled by Du Bois, they all remain within a middle-class aesthetic--indeed, claiming a middle-class space uniquely for African Americans. While undoubtedly challenging the racist images of the day, these images and images like them by Harlem Renaissance photographer James Van Der Zee ignore working-class African Americans and enforce a disciplinary gaze on black bodies that do not conform to a unitary, middle-class aesthetic. The portraits also create the perverse impression that segregation does not affect black chances at life and confirm that "separate-but-equal" produces a greater sense of propriety and decorum than do militant demands for change. As Wright bluntly states in the preface to 12 Million Black Voices, "[T]his text ... does not include ... those areas of Negro life which comprise the so-called 'talented tenth."' (48)

I would also suggest that Wright's insistence on the documentary gaze implicitly critiques a more contemporary and postmodern move to deny the public sphere as a site of contestation. As Nancy Fraser writes, the public sphere's pretense of inclusion merely masks the exclusionary nature of racial-democratic project, granting those with access to that sphere the right to speak for those it implicitly denies. For those who do enter the public sphere, their discourse is shaped by the classed, raced, and gendered concepts of the democratic majority. Bell hooks suggests the ways in which snapshots and family photography can act as a sites of contestation challenging the racial documentary gaze of white visual culture, writing that "the walls and walls of images in Southern black homes were sites of resistance." (49) She further suggests we consider these 
homes as "gallery spaces," implying that they can be seen as, or replace the function of, sites of public cultural production. Hooks shares with Wright the critical emphasis on image production and representation as crucial to producing the terrain of struggle, as well as his emphasis on the democratic potential of technology: "[T]he camera was the central instrument by which black could disprove representations of us created by white folks." (50) Yet, hooks seems to abandon the possibility of, or the need to, address images of African Americans to a greater public. If the home functions as a "gallery," what does it mean for the dissemination of images within a privatized postpublic sphere? Wright's insistence on the publicness of his project, engaging the FSA to procure images, suggests a far more militant and confrontational approach to black documentary. One could say that Bigger Thomas's struggle is not merely to produce images, but rather to take power over image production. Bigger wrests the production of the gaze from Mary and constructs--if only for a brief moment--a public documentary history of black life on the South Side.

Yet, Wright's (and Bigger's) claim on the documentary public sphere, even with images that he did not author, is not without precedent among African American activists. As Leigh Raiford argues, antilynching activists in the 1910s up through the 1930s consciously decided to release once-suppressed

images of lynching to the public as part of the decades-long struggle to enact a federal lynching ban. (51) Given that images of lynching already circulated within at least part of the public sphere as postcards and other forms of photo-documentation, the decision by the NAACP and other activists to release lynching images was not as obvious as it might seem. That is, to put it another way, if circulating images of lynching was already employed to solidify communities of whiteness and to terrorize African Americans, circulating the same images would seem to be a risky endeavor, to say the least, especially considering the unequal power dynamics of the public sphere. Yet, lynching images--as well as mug shots and other racial regimes of visual documentation--existed only within certain privileged spheres of knowledge. Part of the power of lynching images, as well as the more official modes of police and medical surveillance, was constituted by particular forms of national disavowal. Indeed, part of the racial difference that photography enforced was its ability to circulate in one public sphere and not another, to be embraced by whites in the South as their exclusive domain but disavowed by whites nationally. (52) Forcing images of lynched African Americans onto the pages of the New York Times in 1922 was more than simply counterpropaganda by the NAACP--one could argue that it was a claim to national citizenship. And, as Raiford argues, by exposing the pathologies of white supremacy to a national discourse, there is a way in which the recirculation of lynching postcards to another, more public venue robs them of their racial power and even undermines the very claims to white supremacy they are supposed to document. (53) Wright's narration over images produced by Rosskam thus has an affect of recontextualizing and reappropriating the FSA for another radical project.

While recirculating images of white terror into a national public sphere is clearly part of Wright's intent in his wartime publication of 12 Million Black Voices, he is hardly naive about the way in which the public sphere shapes the act of seeing. Wright's first sentence in 12 Million Black Voices explicitly challenges the gaze implicit in a documentary regime of knowing, denying that 
the white viewer can know anything about the black subject by the very means that the book has organized to display the African American's life:

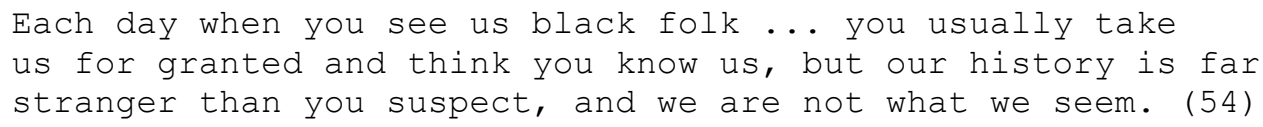

The text further undermines the reader's confidence that the camera can be relied on to document and produce racial knowledge. (55) In a book about African Americans, the first image is a cropped photograph of a white sharecropper who appears at first glance, thanks to the soil on his arms and hands, to be black, suggesting limitations to the understanding one can gain through visual representations of race. Such claims of racial contingency continue throughout the text, as Wright suggests the term "Negro" less describes a people so much as an historically contingent "fiat" of "American history": a fiat that "artificially and arbitrarily defines, regulates, and limits in scope of meaning the vital contours of our lives." (56) Eschewing a biological or essential understanding of race, Wright attempts to undermine the modern history of documentary photography to do just that: to deploy photography as a means to claim the inherent primitivism of classed and raced subjects.

Unlike Du Bois, however, Wright refuses to simply claim the opposite: that African Americans have thus achieved a pinnacle of civilization. It must be remembered that, for Wright, double consciousness is not only a dialectic of racial looking (seeing oneself through the eyes of others) but also of history. As Wright states in the conclusion of 12 Million Black Voices, African Americans "stand today with a consciousness and memory such as few people possess," due to the vast distance of history they have traversed in such a short time: "Hurled from our native African homes" to "the very center of the most complex and highly industrialized civilization the world has ever known," we see that "three hundred years in the history of our lives is equivalent to two thousand years in the history of white folks." (57) For Wright, African Americans both embody a premodern past and a modern present, a feudal mode of production in the South from which they are escaping and a messianic future from which they are excluded. As a visual project, Wright invites America "to look into the mirror of our consciousness and see the living past living in the present," emphasizing the way in which this double history of race can be made to point back visually to the modern project and display its incompletion. (58) "Racial subordination," Paul Gilroy ironically comments, "can ... propel into modernity some of the very people it hopes to dominate" and, for Wright, do the converse: complete the modernist project their oppressors began. (59)

Thus, for Wright, the black migration north into Chicago is more than just black, working-class self-activity or a statement of restrictive material condition--it is an entrance into modernity. Despite chronicling the effects of one-room kitchenettes and segregated living quarters, the pathology of overcrowded living quarters, police brutality, and economic exploitation, Wright maintains that the journey north is not merely one of regional configurations of a racist state, but also one of moving through historical modes of production: "[I]t is when we ... are pushing levers rather than dust cloths that we are gripped and influenced by the worldwide forces that shape and mold Western civilization." (60) The final chapter of the book, "Men in the Making," opens with a portrait of a strong-jawed, clean-shaven young man with welding goggles perched 
on his hat, suggesting a marked contrast with the wild-haired sharecropper in overalls at the opening of the collection, and a clear portrait of the dignity and self-possession granted by "entering Western civilization," even at the bottom rung. Whereas Wright describes the same journey from "feudalism" to "modernity" in American Hunger, in 12 Million Black Voices he locates this disjunction between the promise of modernity and its actual experience at the core of the black experience. As Cedric Robinson similarly suggests in Black Marxism four decades later (1983), Wright locates the beginnings of modernity not with industrialism in England, but with slavery, with the planters "escaping from the fetid medieval dens ... these men leaped upon the road of progress." (61) This also implicitly places the slaves simultaneously at the center at the same time they are the victims of the modern world. Thus, one could see 12 Million Black Voices as a drama of black modernity as much as it is a question of photographic representation.

One must remember that modernity for Wright is a complex contradictory process. As Immanuel Wallerstein points out, the same system that produces universalist discourse through the objective value of the commodity and the homogeneous nature of waged industrial production also produces the opposite: a labor system segmented along axial lines of race and geography. (62) As Cedric Robinson notes, for Wright, unlike some Marxists of the Second International and the Third Period, modernity had no guaranteed teleology. Wright agreed with Marx that the introduction of capitalist modes of production and consumption led to the destruction of precapitalist cultural and social forms of organization, yet had no faith or belief that socialism was a likely outcome of such destruction. (63) Capitalist modernity was experienced by Wright and, he argued, by other African Americans with a profound sense of disequilibrium, experiencing simultaneously both the most advanced forms of industrial progress and "the most direct exposure to racist brutality and brutalization" at the hands of the same bourgeoisie. (64) As Robinson states, "[U]nlike Marx, Wright anticipated barbarism and socialism," suggesting that not only does capitalism contain no end point, but that even the adoption of a socialist economy would not necessarily alter the axial conditions of African American labor and citizenship. (65)

As this tension between the universalism implicit in expanding markets and the particularism of racial practice is felt most viscerally and violently by the victims, so, Wright argues, it also makes the most sense that these victims would be the first to demand full universal rights: thus, those excluded from modernity are those who feel most intensely the need to fulfill its liberal project. One can think of Bigger Thomas gazing at the airplane that he is denied the opportunity to fly in the opening pages of Native Son, or Bigger's nearly successful attempt to master the media codes that entrap him, as speaking to this position. It is precisely Bigger's status as an outsider brought within the orbit of modern institutions that makes him, in Wright's eyes, a protorevolutionary figure. (66) Expressed in materialist terms, a "black proletariat" had developed a "psychic and cultural identity independent of bourgeois ideology" due precisely to its simultaneous awareness of and exclusion from capitalist modes of development. (67)

In Paul Gilroy's seminal work on modernism and double consciousness, he frames the same contradiction by quoting Wright as saying that he was "ahead of Western civilization" precisely because he had experienced its most brutal conditions. (68) This contradiction is expressed most succinctly in Wright's essay about African independence revolutionaries, "The Miracle of Nationalism in the African Gold Coast" (1957): "By enslaving" the educated class of Ghana and granting them access to a modern education, "Britain had liberated them" (69) --not in the sense 
that imperialism is a liberatory project, but rather in that the few Africans Britain allowed an education thus learned the tools to build a free Africa. In Wright's view, the Communist Party in the United States was not merely a radical political project, but rather a way to bring the full promise of modernity to those most in of need it: the Communist Party's John Reed Clubs were Wright's "first contact with the modern world" and had a special meaning for him "that could not be imagined by the white members." (70)

Photography, as both a symbol and a producer of modernity, thus had a unique meaning for Wright. As Paula Rabinowitz suggests in her key work on documentary photography, They Must Be Represented (1994), the documentary is implicitly historical, constructing a subject with or for whom agency must be taken to configure an alternate future. (71) In this sense, the radical documentary is by nature a modernist genre, claiming a negative present as a way to construct a futurity of its redeemed materials. Wright's intense engagement with both modernity and African American subjectivity thus accounts for the many dissonances in the 12 Million Black Voices: Wright deploys a first-person-plural voice speaking for the collective history of African Americans at the same time the project uses the work of white photographers; the narrative insists that the documentary cannot record black life, and yet in many instances the photos serve to illustrate social conditions such as the cramped quarters in kitchenettes or the brutality of the Chicago police; and the book emphasizes the contingency of race and yet, of course, is the story of racial people. Wright insists on both the limitations of the present and the possibility of a transformed future; the contingency of race and yet its messianic meaning; an African American modernity as well as African Americans' exclusion from modernity; and a future that the documentary image can be one part of repairing.

Wright's negative dialectic of modernity is represented by a relentless disequilibrium of linked, rapid-cutting montages, often backed by Rosskam's careful editing of the FSA photos. (72) Montage is, of course, a typical documentary construction deployed in many of the best-known Popular Front documentaries, including the famous tanks/tractors scene in Paul Laurence's The Plow That Broke the Plains (1936) and the birth/ beating images from Herbert Biberman's The Salt of the Earth (1954). For Wright, the montage includes suggestive, radical juxtaposition, as well as an intense telescoping of historical contradiction. In part 3, "Death on the City Pavements" montages such as the photo of white police beating a black man in a suit are contrasted with the sharp, bodily contortions and wild expressions of the joy of black youths dancing; the expressions of meditative prayer and solemn silence are contrasted with the pensive stares of black youths in long, empty hallways and city streets. Yet, the montages do more than just suggest the violent vicissitudes of black life in Chicago; many forcibly take the reader both forward and backward in history nearly simultaneously, expressing the violent dialectic of historical progress that Wright holds is unique to black life.

In the new world of the modern city, often the very processes of modernity carry with them a simultaneous echo of the Southern past: the "handling picks" and "swinging hammers" and "pushing levers" that project black workers toward the modernist "vortex of urban life" are visually doubled with the modern "spikes, knives, guns" that the black worker must bring with him to battle "white mobs." (73) Conversely, underdevelopment of black neighborhoods--the way "streets remain unlighted at night; violations of fire laws go unpunished; garbage piles up in our alleyways; pavements fall into disrepair" is compared to an "aerial bombardment," fusing the 
terror of modern warfare just unleashed with Nazi air raids over Warsaw and Guernica with the primitive conditions of black slums. (74) This condensed historical simultaneity is expressed most clearly in the portrait of the modern black worker in a steel mill (figure 2), his welding goggles perched over a torn and battered hat, his buttoned work shirt frayed at the collar, visually representing the forward and backward motion of history in a single image.

It's important to note that other critical works documenting African American life appeared in the 1930s and 1940s, such as Aaron Siskind's Harlem Document and Gordon Parks's portraits of Ella Watson, yet neither of these for all of their subtlety and self-reflexivity around the act of documentation bring this historical dimension to bear. (75) As the editor and author of the only book-length documentary project of the golden age of documentary photography to attempt to capture the great migration of African Americans, Wright transforms a documentary project conceived to discipline and marginalize black bodies and does so not simply to claim a black documentary voice, but rather to reclaim a modernist project of transformation for black people.

That this is Wright's most optimistic book and documentary should be no surprise--it ends on the affirming note of social and political change, that "we are with the new tide ... voices are speaking. Men are moving! And we shall be with them." (76) Equally, the book imagines a future of integration--an integration that is also transformative for white people, suggesting that the white men who "break bread with us ... differed from those we had known on the plantations; they were not 'po' white trash." (77) In highlighting the interdependency of racial construction between blacks and whites, Wright also implies the interdependency in the production of a modern capitalist world, from the inception of slavery to the present. Yet, it is also a text marked by stark visual contrasts and juxtapositions, suggesting that the black entrance into modernity is not the straight line of progress that Enlightenment histories would make it seem. Wright refuses the invitation of the photo-documentary to "fix" meaning or record a stable truth. One could say that, for Wright, documentary is the voice of radical modernity, entering the future, as Walter Benjamin wrote, by facing the wreckage of the past. As Adorno writes in another context, "[D]ialectics is the consistent sense of nonidentity"--it is a sense of self based in constant transformation, laying claim to the future by the simultaneous negation of present and past. (78)

\section{"Failing to Visualize": Refusing to Document as a Political Act}

When Wright applied to the Film Board of Canada for funds to make a documentary about the underground railroad, he explained that the "very nature" of the subject material rendered the project "impossible to accomplish in the United States." (79) Yet, the same dialectical strategies that serve Wright to create a visual documentary form of double consciousness in the United States fail him distinctly abroad. Black Power, Wright's nonfiction documentary travelogue of the Gold Coast during the independence movement led by the Convention Peoples's Party of Kwame Nkrumah, is a chronicle of Wright's own documentary impulse, attempting many of the same documentary strategies he employs in Black Voices. Wright-as-photojournalist is ubiquitous in the text, while he photographs everything from village life to political rallies in the incipient black republic. According to Sara Blair, Wright took some 1,500 photographs while in the Gold Coast, and, indeed, the first edition of Black Power released in Britain did contain a 
dozen images of the soon-to-be Ghanaians. Yet, for all of Wright's photo-documentation and the initial release, every subsequent printing has been accompanied by no images--and, indeed, I would suggest that text's narrative is framed by Wright as a failure to represent the Ghanaian people visually. Many of the contradictions that create the powerful visual and literary texts of Black Voices and Native Son ironically anticipate his own failure to become the documentarian on the West African coast. Whereas some have suggested that Wright's "failure to visualize" life in 1950s Ghana is due to his own allegiances to Western modernity, I would suggest quite the opposite: Wright's own contradictory feelings about modernity prevent him from rendering Africa in its telescopic gaze.

Black Power begins much like Black Voices, with many of the same textual moves designed to destabilize regimes of racial looking, as well to remind the reader of the way in which the production of an ostensibly white Western civilization has, from its inception, been intertwined with the question of racialized labor. Departing from England to Ghana, Wright observes Liverpool as his boat pulls out of the harbor, noting that "the slave trade built Liverpool docks; the foundations of the city were built of human flesh and blood." (80) Yet, Wright follows this point by immediately observing "how calm, innocent, how staid Liverpool looked in the July sunshine! What massive and stolidly built buildings!," suggesting that, by their visual appearance alone, they denied the truth of their origins. The disjunction of these two observations is compounded by a working-class Englishwoman who tells him "the colonies" will "have to go it on their own ... we've had enough of carrying them on our shoulders." In addition to destabilizing the ability for close and direct observation to reveal the truth about African American life, Wright further seems to suggest that this very empiricism creates divergent and racialized visions of reality. Indeed, Wright seems to imply, what else could this woman know given the visible evidence in front of her?

This image of a blood-soaked Liverpool now stolidly shining in the sun is reproduced, as though by camera obscura, by a Nigerian colonial official Wright meets on the voyage from England. An African judge appointed by the British, the man reveals a distinctly Occidental distaste for "tribal Africans": "you don't know Africa ... there are men in Nigeria who still enjoy human flesh ... they are not ready for freedom." (81) When Wright asks him if he thinks the American colonials were "ready," the judge reverts to absolute definitions of cultural difference, claiming that Africans are "not the same" as European colonial settlers. The Wright-narrator finally erupts: "[I]f you were not black, I'd say you were an Englishman. In fact, you are more English than many English I've met." (82) Wright's construction of this scene works in part to distinguish the Western-educated Nkrumah and his mass-based political movement from the black elite of Africa, but, as importantly, to undermine biological assumptions of race based on an regime of looking The man shares with the narrator his black skin, but the man's ideology and class position end up suggesting more about him than a common racial identity. Although the "blood" of Africans may have founded the British Empire, the same shared blood and race do not make by themselves a community.

This intensely historical, contingent, and nonbiological view of racial construction places Black Power firmly in line with Wright's other works of fiction and nonfiction. Yet, this same perspective that lends itself so vividly to a millenarian view of social and personal transformation utterly fails the Wright-narrator in this work of literary journalism. Wright is continually unable 
to find a sense of community and purpose in the Gold Coast, and often vacillates wildly between feelings of alienation and identification with the residents of the British colony. Numerous scholars have pointed out the quality of disorientation and cultural shock Wright experiences upon arriving in the still-British colony, frequently vexed by tribal villagers, kept at arm's length by Nkrumah's Convention People's Party, and unpleasantly courted by often-racist colonial officials and the African administrative elite. Whereas some (such as Kwame Appiah and Ngwarsungu Chiwengo) have described Wright's fluctuations between gestures of solidarity and feelings of alienation as a kind of surrender to conservative colonial narratives of Eurocentric progress, others (such as Pratt and Gilroy) have emphasized the way in which Wright's often contradictory and ambiguous experiences can be considered part of a larger struggle to articulate a hybrid, postcolonial language and identity. (83) Blair argues that Wright seems to almost "purposely undermine" his own "documentary agency," suggesting that both perspectives are true for Wright. He is a proponent of a modern, independent Ghana free of colonial underdevelopment (84) but also is aware that modernity--as a mode of visual expression--cannot free itself totally from the "production of racial truth" as he once seemed to believe. He is thus left with an "empty space of future"--a future that both carries forward a universalist Enlightenment project and yet breaks with that project's own historical development and ocular modes of representation and categorization.

Tellingly, many of Wright's most profound moments of doubt in Black Power are narrated through the trope of photography. Indeed, Wright's own self-portrait--a pith-helmeted, anthropologist-quoting, camera-wielding figure with a private chauffer ("I sit in back," Wright informs a curious colonial businessman) verges on self-satire. (85) In what amounts to a repeated symbol in the text, Wright's frequent attempts to construct a documentary vision are subverted by the locals or fail due to Wright's own shock at what he perceives. The camera is displayed as the central marker of Wright's modernity and is recognized by the Ghanaians themselves as one of the objects that sets him apart from them. Consider the following scenes:

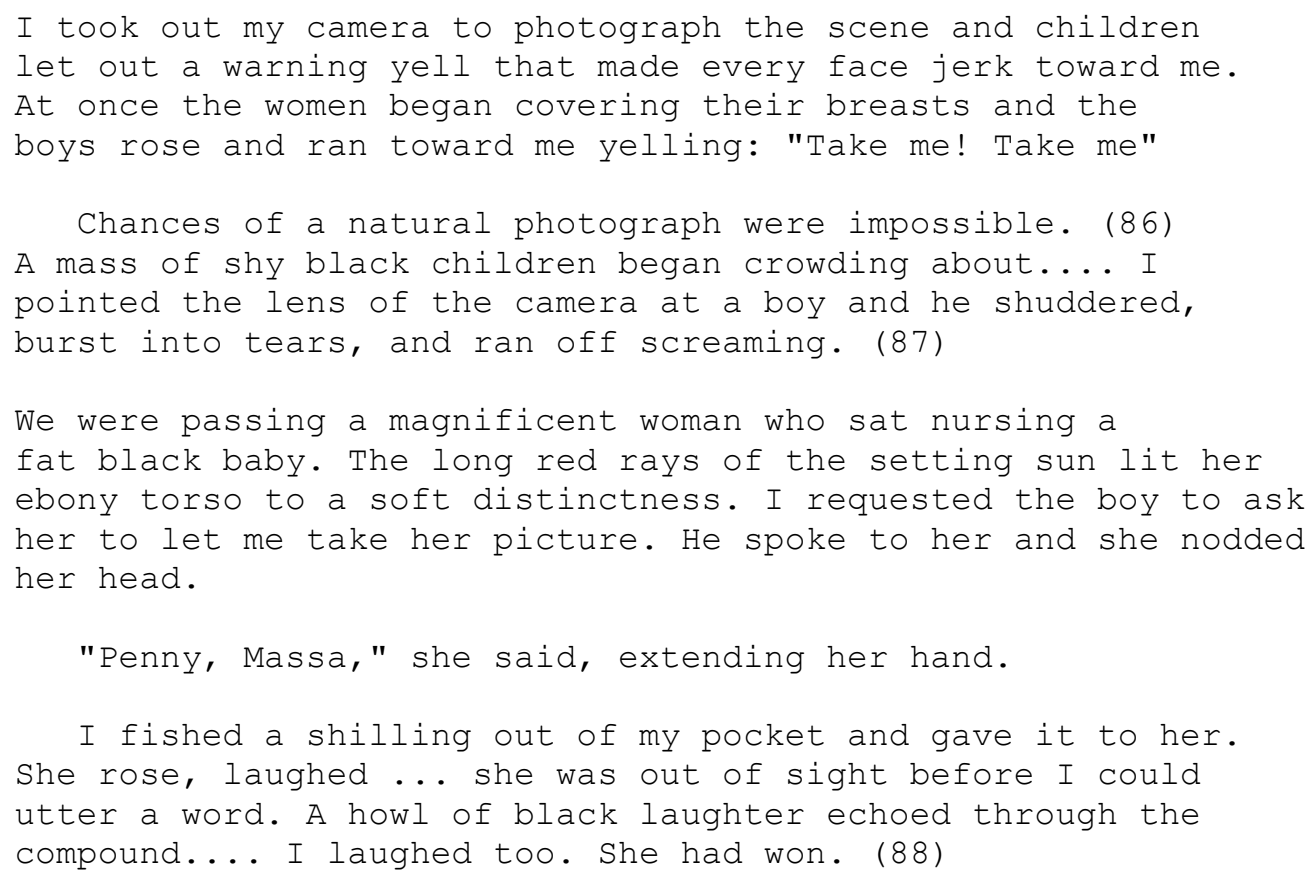


The camera is denied its role as a passive, mechanical observer. The Ghanaians seem keenly aware that the camera is a special mode of seeing, that it constructs and is not merely an adjunct to a Western gaze for which the women must cover their breasts and small boys feel an intuition of either horror or opportunity. That the last of these three scenes prompts Wright to experience the moment of doubt discussed in the previous paragraph suggests the extent to which Wright simultaneously identifies with the gaze of the camera and understands the nature of the Africans' resistance.

Wright's faith in the possible liberatory power of industrialism is humorously shaken when a "young lad" asks for his camera, insisting that Wright's camera--wielded by a black man--will be different from the same camera the boy could buy in an Accra market. (89) Wright argues with the boy until "finally I understood what he meant. He was trying to tell me that be believed the British would ... take out some valuable part of the camera before they sold it to him, an African." (90) The boy's naive request nonetheless exposes a central difference in his view of the modern world. Despite acknowledging the racial history of modern development, Wright believes that the machine age would act as a mode of liberation and independence for Ghana, whereas this boy--far too literally perhaps--understands that modernity, in its very inception, cannot be racially neutral. The camera sold to the Africans would not be same camera manufactured and used by the British.

This is not to suggest of course, a "dark" primitivism and a "white" modernity, but rather to acknowledge as Cedric Robinson argues in Black Marxism that industrial modernity was founded on the production of racial difference from its germination in the Middle Ages, and that its application in the Third World would not bring freedom but further entrapment in the world system. (91) In a remarkable scene, Wright registers the nonobjective nature of documentary observation:

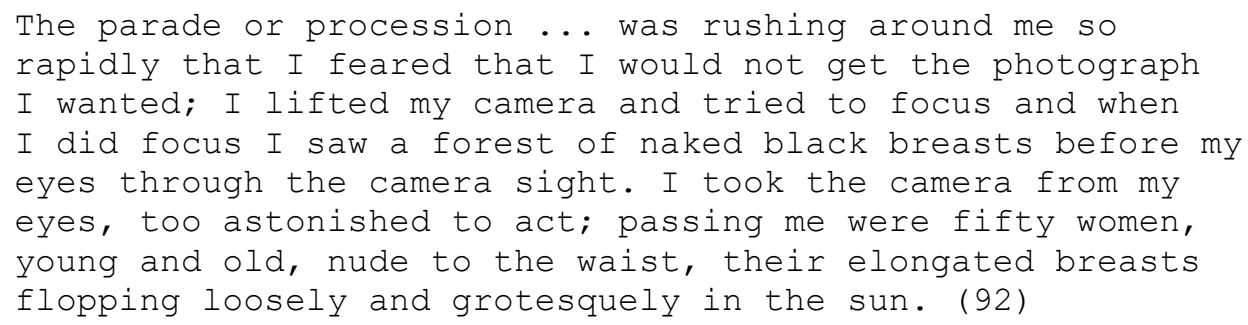

It was not, of course, the first time Wright had seen naked women in Ghana, and, indeed, he remarked repeatedly on how normal it seemed after living there for a time to see women's uncovered breasts. Rather, I would suggest that it is precisely because Wright views the scene through his viewfinder that he registers--perhaps the only time in the text--a visceral disgust for African custom. Although Wright clearly disapproves of many of the pagan practices of the tribal chiefs, he is usually careful to maintain it is merely for political reasons in that tribal customs reinforce the power of the chiefs and ultimately British rule. That Wright gazes through the viewfinder while expressing visceral disgust with African custom and African flesh says as much about the camera as a mode of looking as it does about Wright, or rather the way in which Wright experiences "double vision" while seeing through the lens of the photo-document. He adopts a white gaze most profoundly while seeing through the visual tradition of photo- 
documentary, thus locating that gaze in a particular modality of modern visual expression. And, unlike in 12 Million Black Voices or even in the faint stabs at mutuality suggested by Jan in Native Son, there is no abstract-universal plane of the public sphere on which to greet the African on equal terms with the camera.

It should thus come as little surprise that the one moment in which Wright identifies with the "reaction pattern" established by "British imperialism" occurs when he asks a taxi driver to take him to the Photo Section of the Gold Coast Information Service to develop film. (93) The driver, accustomed to taking orders without question, drives randomly through the city until it's revealed he's never heard of the Photo Section and finally drives Wright to the headquarters of the British Military Command for West Africa, thus displaying the connection in at least one Ghanaian's mind between photography and military occupation. Indeed, the final moment before Wright decides to leave the Gold Coast and head back to Europe comes as he tries to photograph a tribal funeral procession and is mistaken for a British agent by a drunk mourner who shouts "Take no picture! I kill you! ... You work for British!" (94) Chased to his car by men wielding long knives, Wright narrates flatly, "I don't know if those painted men with long knives were successful in scaring away the dead man's spirit or not; all I can say is they scared the hell out of me.... Next day at noon I told Kojo to drive nonstop to Accra." (95) The following day, Wright decides to leave Ghana and return to Europe. Thus, we have to ask, what does it mean that Black Power ends as Native Son begins--with the "murder" of a documentarian--in this case, of Mr. Wright himself as he is chased out an Ashanti village at knifepoint?

In one sense, the answer seems fairly straightforward. Wright obviously casts himself much like Mary Dalton in Native Son, an outsider motivated by feelings of solidarity to want to understand and document the struggles of a culturally different subaltern class--and is thoroughly rebuffed and even ridiculed by those he wants to understand. This move underscores the importance of Wright's insistence on the first-person plural in 12 Million Black Voices. Rather than read the first person plural as an attempt to construct a homogeneous African American experience, for Wright the ability to document a people's experience must grow organically from being a part of that people's history. Wright's refusal to represent the Ghanaian people in documentary photographs (rather than the more subjective genre of first-person narrative journalism) may be at least one of Wright's final statements about the relationship between the African diaspora and the homeland of Africa. Rather than suggest that Wright sees no commonality, to refuse to represent can also be seen as a democratic act--that for whatever Wright may personally believe about the best course of action for the anti-imperialist movements of Africa, he ultimately refuses to grant his vision the authoritative voice of the documentary image, implying, of course, that it is for the Africans to do themselves. Fittingly, one of Wright's final recorded interactions with a Ghanaian takes place as he buys an of out-of-print anthropological text from an Ashanti "wandering nomad." After a brief conversation, Wright confesses that he "tried to visualize" the man's life, roaming among various members of his extended clan, "but I could not." (96) Wright concludes his narrative as a "failure to visualize" what he grasps as the central political fact about Ghanaian life: its tribal relations. We can take this statement quite literally: it is precisely Ghana's tribal life that prevents Wright from creating his photo-documentary.

Yet, there is also a way in which refusing to document though visual imagery can be read as an acknowledgment of the realpolitik of the visual image. As David Marriot writes, "[R]ace is 
embedded in the medium" of photography. (97) There is a silent acknowledgment that the documentary mode inherently carries within it a certain teleology of modernity that does not recognize alternative paths. Unlike 12 Million Black Voices, in which modernity is recognized by ocular symbols--neat hair, shaved faces, industrial employment, a confident, self-possessed gaze--the process of entering Africa into the modern world would entail the creation of a massbased political party that could reach out to tribal Africans symbolically as well as programmatically. As Wright imagines the conversation among the six independence leaders of Ghana in his 1950s lecture series White Man, Listen!, one says, "We must ... doff our Western clothes and wear the clothes of our tribes ... in order to win the confidence and allegiance of the masses ... though dressed in tribal clothes, we must always use the most modern methods in organizing." (98) It is a remarkable passage, for it suggests that the route to modernity for Ghana is through the embrace of the premodern, the very kind of "visual savagery" that Wright sought so hard to avoid in his own visual acts of representation.

Described in both White Man, Listen! and Black Power, Nkrumah forms a "modern political organization" by using "tribal symbols"--a hybridity expressed through the incorporation of tribal ritual into mass political rallies. If documentary brings the "past into the future," then representing the ways in which the future must be brought into the past, so to speak, not only frustrates the documentary aesthetic but cannot be represented visually. There is no visual truth that Wright can produce for a Western audience that will show Ghana's leap into the future. The racial project of African liberation, embedded visually in a tribal world, relies on the appearance of difference rather than sameness. Wright's and Du Bois's visual strategy of rendering modern African-descended people would be understood in Ghana as yet another form of colonial domination. If race is a series of visual markers, then Nkrumah's hybrid project cannot be represented by the same documentary gaze that reads tribal togas and the "Nazi-like" salute of the Convention People's Party outside of the realm of the modern. It is Wright's dialectic of black modernity thrown on its head.

One could say Black Power has three distinct endings: There is Wright's final letter to Kwame Nkrumah in which Wright advocates a psychological "hardening" in order to build a modern African state free from Western influence and powers. There is Wright's "failure to visualize" the basic political structure of African tribes. And then there is Wright's final trip in the Gold Coast, to the castle that served as a slave-trading post for hundreds of years. Responding to the rumor that "gold" is buried in the depths of the castle fortress, Wright laments that while one "likes to think" that hidden in the walls are "thousands of tons" of gold, there is a "sheen that outshines gold--a tiny, pear shaped tear that formed on the cheek of some black woman torn away from her children ... unredeemed, unappeased." (99) One could read the refracted light on this woman's tear as the dialectical opposite of the modern "second-sight" Wright represents with the camera in 12 Million Black Voices--looking to the past rather than a dialectic that can propel Wright into the future. If double consciousness is embedded in an act of seeing for Wright, then he seems to imply through his constant failure to photograph Ghanaians that the representational strategies of modernity--based on a refraction of the ocular gaze--are not appropriate for postcolonial Africa. The unique modernism produced from what Gilroy refers to as the "intensity of feeling" that comes from "seeing" modernity from the outside-in is perhaps an experience rooted in a diasporic consciousness--that modernity and all of its "anxiety and doubt" is the emotional register of exile. In some ways, one can read a second meaning into the unredeemed tear of the 
slave sold into bondage in the New World: that her suffering--and what Wright saw as the new consciousness that is the sole benefit of her suffering--did not travel back across the sea to Africa. Whether this suggests that we reread Wright's endorsement of modernity in Native Son, American Hunger, and 12 Million Black Voices as limited, compromised, and embedded in ocular practices of the West, or that we read Nkrumah's hybridity as limited, Wright seems unable to answer. Either way, or both ways, in killing Mary Dalton, Wright also had to put down his own camera when in the soon-to-be nation of Ghana.

\section{NOTES}

I thank Jake Mattox and Joo Ok Kim for reading early drafts of this essay and providing their sharp insights and patient, helpful feedback. I also thank the blind reviewers for Criticism for their hard work and for their uncompromising suggestions for revision, and especially the Indiana University students in my English L680 class for finding Native Son as gripping as I did the first time I read it.

(1.) Richard Wright, Native Son (1940; repr., New York: Harper Perennial, 2005), 69.

(2.) Paula Rabinowitz, They Must Be Represented: The Politics of Documentary, Haymarket Series (New York: Verso, 1994), 58.

(3.) Richard Wright and Edwin Rosskam, 12 Million Black Voices (1941; repr., New York: Basic Books, 2008), 146-47.

(4.) Ibid., 12.

(5.) Maurice O. Wallace, Constructing the Black Masculine: Identity and Ideality in AfricanAmerican Mens Literature and Culture, 1775-1995 (Durham, NC: Duke University Press, 2004), 135. See also Sara Blair, "Documenting Harlem: Images and Afterlives," in Harlem Crossroads: Black Writers and the Photograph in the Twentieth Century (Princeton, NJ: Princeton University Press, 2007), 19-60; Joseph B. Entin, Sensational Modernism: Experimental Fiction and Photography in Thirties America, Cultural Studies of the United States (Durham: University of North Carolina Press, 2007); and Abdul R. JanMohamad, The Death-Bound-Subject: Richard Wright's Archaeology of Death, Post-Contemporary Interventions (Durham, NC: Duke University Press, 2005)

(6.) Michel Fabre, The Unfinished Quest of Richard Wright (New York: William Morrow, 1973), 261.

(7.) Shawn Michelle Smith, American Archives: Gender, Race, and Class in Visual Culture (Princeton, NJ: Princeton University Press, 1999), 4.

(8.) Ibid., 3-10.

(9.) Ibid., 92. 
(10.) Deborah Willis, "Introduction: Picturing Us," in Picturing Us: African American Identity in Photography, ed. Deborah Willis (New York: New Press, 1994), 3-28, quotation on 17.

(11.) Maren Stange, Symbols of Ideal Life: Social Documentary Photography in America 18901950 (New York: Cambridge University Press, 1989), 18.

(12.) Ibid., 14.

(13.) See Joy S. Kasson, Buffalo Bills Wild West: Celebrity, Memory, and Popular History (New York: Farrar, Straus, and Giroux, 2000). Kasson discusses the way Buffalo Bill's Wild West Show enabled viewers to experience the vicarious thrill of the West while also constructing an implicit justification and myth of conquest.

(14.) Rabinowitz, They Must Be Represented, 58.

(15.) Nicholas Natanson, The Black Image in the New Deal: The Politics of FSA Photography (Knoxville: University of Tennessee Press, 1992), 4. On the same page, Natanson quotes Roy Stryker's instructions to Dorothea Lange: "'Regarding the tenancy pictures,' he replied to her inquiry from Texas, 'I would suggest that you take both black and white, but place the emphasis on the white tenants, since we know that these will receive much wider use."'

(16.) Smith, American Archives, 92.

(17.) Erskine Caldwell and Margaret Bourke-White, You Have Seen Their Faces (1937; repr., Athens: University of Georgia Press, 1995), 22.

(18.) Ibid., 14.

(19.) Ibid., 16-30.

(20.) Ibid., 2.

(21.) Nicholas Natanson, "Politics, Culture, and the Black FSA Image," Film \& History, 17, no. 3 (1987): 26-42.

(22.) Natanson, Black Image, 1-3.

(23.) Ibid., 71. For good critical overviews of Aaron Siskind's Harlem Document, a collection of photos from the 1930s that was published in 1981, see Joseph Entin's "Modernist Documentary: Aaron Siskind's Harlem Document," Yale Journal of Criticism, 12, no. 2 (1999): 357-82; and Sara Blair's "Documenting Harlem: Images and Afterlives," in Harlem Crossroads (see note 5), 19-60. I also discuss Siskind's photos in greater detail at the conclusion of the section "12 Million Black Voices and Black Modernity."

(24.) Natanson, Black Image, 49-50. 
(25.) C. L. R. James, "Stalinism and Negro History," in C. L. R. James and Revolutionary Marxism: Selected Writings by C. L. R. James, 1939-1949, ed. Scott McLemee and Paul Le Blanc Revolutionary Studies (New York: Humanities Press, 1994), 179-87, quotation on 188-89.

(26.) Ibid., 182-83.

(27.) I would argue that Siskind's photographs, while granting a unique complexity to their subjects and troubling the role of the photographer, do not present "double vision" as an historical process of the journey into modernity as Wright insists for his own images.

(28.) Amrit Singh, introduction to the Harper Perennial Edition, in Black Power: A Record of Reactions in a Land of Pathos, by Richard Wright (1954; repr., New York: Harper Perennial, 1995), xxi--xxxix, quotation on xv.

(29.) Richard Wright, "Joe Louis Uncovers Dynamite," in Richard Wright Reader, ed. Ellen Wright and Michel Fabre (New York: Harper and Row, 1997), 31-35, quotation on 32.

(30.) Ibid., 32, italics in the original.

(31.) Joseph B. Entin, Sensational Modernism: Experimental Fiction and Photography in Thirties America, Cultural Studies of the United States (Durham: University of North Carolina Press, 2007), 220.

(32.) Wright, Native Son, 33.

(33.) Ibid., 33-34.

(34.) Ibid., 336.

(35.) Entin, Sensational Modernism, 242.

(36.) Wright, Native Son, 429.

(37.) Ibid., 74.

(38.) Ibid., 247.

(39.) Ibid., 251.

(40.) Ibid., 254.

(41.) Ibid., 247, 254.

(42.) Ibid., 362.

(43.) Ibid. 
(44.) JanMohamad, Death-Bound-Subject, 80.

(45.) Wright, Native Son, 289.

(46.) Shawn Michelle Smith, Photography on the Color Line: W. E. B. Du Bois, Race, and Visual Culture (Durham, NC: Duke University Press, 2004), 6.

(47.) Ibid., 27.

(48.) Wright and Rosskam, preface to 12 Million Black Voices (see note 3), xx-xxi, quotation on $\mathrm{xX}$.

(49.) bell hooks, "In Our Glory: Photography and Black Life," in Willis, Picturing Us (see note 10), 43-55, quotation on 47.

(50.) Ibid., 48.

(51.) Leigh Raiford, "No Relation to the Facts about Lynching," in Imprisoned in a Luminous Glare: Photography and the African American Freedom Struggle (Chapel Hill: University of North Carolina Press, 2011), 29-66.

(52.) As an analogy, one could think of the images of Abu Ghraib that lost their power to intimidate Iraqis once the images were transferred to pages and screens of elite media in the United States.

(53.) Raiford, Imprisoned in a Luminous Glare, 34-35.

(54.) Wright and Rosskam, 12 Million Black Voices, 10.

(55.) For Entin's subtle reading of the way 12 Million Black Voices destabilizes regimes of racial knowledge, see his Sensational Modernism (245).

(56.) Ibid., 30.

(57.) Ibid., 146

(58.) Ibid.

(59.) Paul Gilroy, The Black Atlantic: Modernity and Double Consciousness (Cambridge, MA: Harvard University Press, 1993), 163.

(60.) Wright and Rosskam, 12 Million Black Voices, 117.

(61.) Ibid., 12. 
(62.) Immanuel Wallerstein, "The Ideological Tensions of Capitalism: Universalism versus Racism and Sexism," in Race, Nation, Class: Ambiguous Identities, by Etienne Balibar and Immanuel Wallerstein (London: Verso, 1991), 29-36.

(63.) Cedric J. Robinson, Black Marxism: The Making of the Black Radical Tradition (Chapel Hill: University of North Carolina Press, 1983), 297.

(64.) Ibid., 289.

(65.) Ibid., 299.

(66.) Richard Wright, "How Bigger Was Born," in Native Son (see note 1), 431-62, quotation on 451.

(67.) Robinson, Black Marxism, 300, 304.

(68.) Gilroy, Black Atlantic, 162.

(69.) Richard Wright, "The Miracle of Nationalism in the African Gold Coast," in White Man, Listen! (1957; repr., New York: Harper Perennial, 1995), 111-42, quotation on 124.

(70.) Richard Wright, Black Boy (1945; repr., New York: Harper Perennial, 1991), 324.

(71.) Rabinowitz, They Must Be Represented, 24.

(72.) Jack Moore notes the use of montage in his essay "The Voice in 12 Million Black Voices," in Richard Wright: A Collection of Critical Essays, ed. Arnold Rampersad, New Century Views, vol. 11 (Upper Saddle River, NJ: Prentice Hall, 1995), 140-47.

(73.) Wright and Rosskam, 12 Million Black Voices, 117-18.

(74.) Ibid., 113-14.

(75.) Aaron Siskind's Harlem Document is perhaps the most significant precursor to Wright's engagement with the photo-documentary. Gathered ultimately in book form in 1981, Siskind's photographs of Harlem in the late 1930s appeared in the new glossy photo-journal Look, as well as in Fortune magazine and Communist Party organs such as the Daily Worker. As one of the more subtle and complex representations of African American life during the Depression, it is important to note the author was not only a Communist Party activist, but that the photos of Harlem, as well as Siskind's political aesthetic, emerged from Siskind's participation with the documentary photography produced by the Communist-affiliated New York Photo League. Siskind sought images that would be urban, complex, and affirmative, while also true to material circumstances. Images of successful business owners, veterans, and small proprietors stand next to images of burlesque dancers in "jungle" outfits before white patrons, presenting a sense of both self-determination and exploitation that stand unreconciled. As Entin points out, Siskind's Harlem photographs are also noteworthy for the self-reflexive discomfort they produce in the 
viewer, "the awkward poses and strained expressions of their human subjects, the contentious glances offered by several individuals he captures on film" that directly challenge the photographer and the regime of racial documentation itself (see Joseph Entin, "Modernist Documentary: Aaron Siskind's Harlem Document," Yale Journal of Criticism 12, no. 2 [1999]: 357-82). And while Siskind's images signify a break with previous modes of documentary representation, Wright's own obsessions with the historicity of the documentary image and with black self-representation suggest that 12 Million Black Voices is a fundamentally different project.

(76.) Wright and Rosskam, 12 Million Black Voices, 100.

(77.) Ibid., 144.

(78.) Theodore W. Adorno, Negative Dialectics, trans. E. B. Ashton (1966; repr., New York: Continuum, 2000), 5.

(79.) Fabre, Unfinished Quest, 261.

(80.) Wright, Black Power, 14.

(81.) Ibid., 18.

(82.) Ibid.

(83.) Dorothy Stringer, "Psychology and Black Liberation in Richard Wright's Black Power (1954)," Journal of Modern Literature 32, no. 4 (2009): 105-24. See also Kwame Anthony Appiah, "A Long Way from Home: Wright on the Gold Coast," in Rampersad, Richard Wright (see note 72); Ngwarsungu Chiwengo, "Gazing through the Screen: Richard Wright's Africa," in Richard Wright's Travel Writings: New Reflections, ed. Virginia Whatley Smith, Margaret Walker Alexander Series in African American Studies (Jackson: University Press of Mississippi, 2001), 20-44; and Mary Louise Pratt, Imperial Eyes: Travel Writing and Transculturation (New York: Routledge, 1992).

(84.) Blair, Harlem Crossroads, 106-8.

(85.) Wright, Black Power, 356.

(86.) Ibid., 75.

(87.) Ibid., 158.

(88.) Ibid., 162-63.

(89.) While Wright is deliberate in his effort to undermine racial and Occidental modes of looking, his faith in the neutrality of modernity can be best expressed in his somewhat remarkable passage early in the text: "[T] he art of manufacture was no longer a secret, and 
machines had a nigger-loving way of letting even black hands operate them," looking forward to the moment that Africa could wrest industrial progress away from Europe and the United States (ibid., 15).

(90.) Ibid., 100.

(91.) Robinson, Black Marxism, 26.

(92.) Ibid., 143.

(93.) Ibid., 193.

(94.) Ibid., 369.

(95.) Ibid., 371.

(96.) Ibid., 374.

(97.) David Marriott, preface to Haunted Life: Visual Culture and Black Modernity (New Brunswick, NJ: Rutgers University Press, 2007), xi--xxiv, quotation on xx.

(98.) Ibid., 116.

(99.) Ibid., 384.

Benjamin Balthaser is assistant professor of English at Indiana University, South Bend. His scholarship, teaching, and creative work investigate the relationships among social movements, racial identity, and cultural production. His current manuscript "Modernism and AntiImperialism: Global Movements and Radical Culture from the Great Depression to the Cold War" explores the connections between cross-border, anti-imperialist movements and the making of modernist culture at mid-century. His critical and creative work has appeared or is forthcoming in such journals as American Quarterly, the Oxford History of the Novel in English, Reconstruction, and the Minnesota Review. 